\title{
EFEKTIVITAS PEMBERIAN BANTUAN PEMERINTAH PADA MASYARAKAT DI KECAMATAN MADAT KABUPATEN ACEH TIMUR
}

(The Effectiveness of The Provision of Government Assistance to The Society in The Madat Sub-District of East Aceh Regency)

\author{
Syibram Malisi ${ }^{1}$, Elvira Iskandar ${ }^{1}$, Ahmad Humam Hamid $^{1 *}$ \\ ${ }^{1}$ Program Studi Agribisnis, Fakultas Pertanian, Universitas Syiah Kuala
}

\begin{abstract}
Abstrak - Pemerintah saat ini memiliki berbagai program penanggulangan kemiskinan yang terintegrasi mulai dari program penanggulangan kemiskinan berbasis bantuan sosial, program penanggulangan kemiskinan yang berbasis pemberdayaan masyarakat serta program penanggulangan kemiskinan yang berbasis pemberdayaan usaha kecil, yang dijalankan oleh berbagai elemen Pemerintah baik pusat maupun daerah. Kajian terhadap efektivitas pemberian bantuan kepada masyarakat miskin perlu dilakuan, agar dapat menentukan proses administrasi program bantuan pemerintah untuk masyarakat desa sudah sesuai dengan ketentuan yang berlaku atau belum. Berdasarkan hal tersebut, penelitian ini dilakukan untuk mengetahui efekttifitas pemberian bantuan pemerintah pada masyarakat di Kecamatan Madat Kabupaten Aceh Timur. Metode penelitian yang di gunakan adalah metode survey. Populasi dalam penelitian ini adalah semua rumah tangga penerima program bantuan pemerintah di Kecamatan Madat Kabupaten Aceh Timur. Hasil penelitian dilapangan diperoleh bahwa proses pelaksanaan pemberian bantuan Proses administrasi program bantuan pemerintah di Kecamatan Madat Kabupaten Aceh Timur yang meliputi Program Keluarga Harapan dan Bantuan Siswa Miskin sudah efektif sesuai dengan ketentuan yang berlaku, sedangkan program bantuan Raskin belum efektif sesuai dengan ketentuan yang berlaku. Rumah tangga penerima bantuan Raskin dan Bantuan Siswa Miskin sudah mengelola bantuan dengan efektif, sedangkan bantuan Program Keluarga Harapan belum dikelola dengan efektif oleh masyarakat di Kecamatan Madat Kabupaten Aceh Timur. Manfaat program bantuan yang mengacu pada indikator pendapatan, pengeluaran, dan tabungan masyarakat belum sepenuhnya tercapai.
\end{abstract}

Kata Kunci : Efektifitas, Beras miskin (Raskin), Program keluarga harapan, Bantuan siswa miskin.

\begin{abstract}
The government currently has a variety of integrated poverty reduction programs ranging from poverty reduction programs based on social assistance, poverty reduction programs based on community empowerment and poverty reduction programs based on the empowerment of small business, which is run by the various elements of both central and local government. The study on the effectiveness of aid to poor communities need was done, in order to determine the administrative process of government aid programs for rural communities is in conformity with applicable regulations or not. Accordingly, this study was conducted to determine efekttifitas provision of government assistance to the people in the District of opium East Aceh district. The research method used was survey method. The population in this study were all of households receiving government aid program in East Aceh District of opium. The results of the field studies showed that the process of implementing aid administrative process of government assistance programs in the District of opium East Aceh District which includes the Family Hope Program and Help Poor Students have been effective in accordance with applicable regulations, while the aid program Raskin have not been effective in accordance with applicable regulations. Raskin beneficiary households and Help Poor Students already manage aid effectively, while the Family Hope Program assistance is not managed effectively by the people in the District of opium East Aceh district. Benefits assistance program which refers to indicators of income, expenses, and savings society has not fully achieved.
\end{abstract}

Keywords : Effectiveness, Poor rice (Raskin), Program families hope, Help poor students. 


\section{PENDAHULUAN}

Indonesia yang merupakan negara kepulauan memiliki beragam suku, budaya dan ciri khas, karenanya dalam melaksanakan pembangunan tentulah tidak berjalan dengan mulus. Salah satu masalah utama yang dihadap Indonesia dalam melaksanakan pembangunan adalah kemiskinan. Tingkat kemiskinan Indonesia yang tinggi sangat mempengaruhi proses pembangunan. Kemiskinan menunjukkan dan menyebabkan kualitas sumber daya manusia yang rendah, karenanya banyak kebijakan pemerintah lewat berbagai program pembangunan yang inklusif terus dilakukan pemerintah agar jurang antara si kaya dan si miskin tidak semakin lebar.

Pemerintah saat ini memiliki berbagai program penanggulangan kemiskinan yang terintegrasi mulai dari program penanggulangan kemiskinan berbasis bantuan sosial, program penanggulangan kemiskinan yang berbasis pemberdayaan masyarakat serta program penanggulangan kemiskinan yang berbasis pemberdayaan usaha kecil, yang dijalankan oleh berbagai elemen Pemerintah baik pusat maupun daerah.

Kajian terhadap efektivitas pemberian bantuan kepada masyarakat miskin perlu dilakuan, agar dapat menentukan proses administrasi program bantuan pemerintah untuk masyarakat desa sudah efektif sesuai dengan ketentuan yang berlaku atau belum dan apakah masyarakat sudah mengelola dan memanfaatkan bantuan tersebut dengan baik.

\section{METODE PENELITIAN}

Metode yang di gunakan dalam penelitian ini dilakukan dengan metode survey. Populasi dalam penelitian ini adalah semua rumah tangga penerima program bantuan pemerintah di Kecamatan Madat Kabupaten Aceh Timur. Dari Kecamatan Madat, diambil 3 desa yaitu Desa Pante Meureubo, Desa Lueng Peut, dan Desa Lueng Sa yang memiliki kepala keluarga bermata pencaharian sebagai petani sawah dan petani tambak lebih besar dari desa lainnya. Penentuan sampel dilakukan dengan teknik pengambilan sampel secara acak sederhana (Simple Random Sampling).

Metode deskriptif kualitatif ini adalah suatu pendekatan dalam memahami kondisi sosial ekonomi masyarakat di Kecamatan Madat Kabupaten Aceh Timur, yaitu memahami jenisjenis bantuan yang diberikan kepada masyarakat tersebut, memahami efektifitas proses administrasi program bantuan pemerintah dan mengetahui bagaimana pengelolaan dan manfaat bagi rumah tangga yang sudah menerima bantuan. Untuk memahami hasil penelitian tersebut diperlukan data-data yang valid untuk mendapatkan hasil penelitian yang maksimal. Pendekatan kualitatif berusaha mengumpulkan data deskriptif yang banyak dituangkan kedalam bentuk laporan yang diperoleh dari catatan lapangan, dokumen, hasil observasi, dan wawancara.

Pengkatagorian skor tingkat efektivitas proses administrasi program bantuan pemerintah dibagi kedalam dua katagori yaitu berdasarkan skor tertinggi dikurang dengan skor terendah dan dibagi dengan jumlah kelas. Tingkat skornya yaitu, sebagai berikut :

A. Efektifitas Proses Administrasi Program Bantuan.

Skor :

$0=$ TidakSesuai SOP

$1=$ Sesuai SOP

Rentang Skor:

Kriteria $\quad: 0-0,49=$ Tidak Efektif

$$
0,50-1=\text { Efektif }
$$


B. Efektifitas Hasil Pengelolaan Bantuan.

Adapun kriteria pengambilan keputusan tentang pengelolaan bantuan pemerintah dibagi kedalam dua kategori skor dan tiga kriteria pengambilan keputusan yaitu, sebagai berikut :

Pengelolaan :

Skor : $\quad 0=$ Pengelolaan tidak sesuai dengan tujuan program bantuan

$1=$ Pengelolaan sesuai dengan tujuan program bantuan

Kriteria keputusan :

- Pengelolaan baik jika $>66,66 \%$ rumah tangga menggunakan bantuan sesuai dengan tujuan program bantuan.

- Pengelolaan kurang baik jika 33,33\% - 66,66\% rumah tangga menggunakan bantuan sesuai dengan tujuan program bantuan.

- Pengelolaan tidak baik jika $<33,33 \%$ rumah tangga menggunakan bantuan sesuai dengan tujuan program bantuan.

C. Manfaat Program Bantuan

Adapun kriteria pengambilan keputusan tentang manfaat program bantuan pemerintah dibagi kedalam dua kategori skor dan tiga kriteria pengambilan keputusan yaitu sebagai berikut :

Skor : $0=$ Program bantuan tidak bermanfaat bagi penerima bantuan

$1=$ Program bantuan bermanfaat bagi penerima bantuan

Kriteria keputusan :

- Baik jika > 66,66\% rumah tangga penerima bantuan mencapai tujuan program bantuan.

- Kurang baik jika 33,33\% - 66,66\% rumah tangga penerima bantuan tujuan program bantuan kurang tercapai.

- Tidak baik jika $<33,33 \%$ rumah tangga penerima bantuan tujuan program bantuan tidsk tercapai.

\section{HASIL DAN PEMBAHASAN}

Karakteristik Responden.

Tabel 1. Kriteria Umur Responden di Kecamatan Madat Kabupaten Aceh Timur, Tahun 2016

\begin{tabular}{ccc}
\hline & Satuan & Rata-rata \\
Umur & Tahun & $41-50$ \\
Tingkat Pendidikan & SD/SMP/SMA/Strata & SMA \\
Jumlah Tanggungan & Orang & $3-5$ \\
\hline
\end{tabular}

Sumber : Data Primer (Diolah), 2016

\section{Jenis-Jenis Bantuan Pemerintah di Kecamatan Madat kabupaten Aceh Timur 1.1 Beras Untuk Keluarga Miskin (Raskin)}

Program Beras Untuk Keluarga Miskin (Raskin) merupakan subsidi pangan yang diperuntukkan bagi rumah tangga berpendapatan rendah sebagai upaya dari pemerintah untuk meningkatkan ketahanan pangan dan memberikan perlindungan sosial pada rumah tangga sasaran. Keberhasilan program Raskin diukur berdasarkan tingkat pencapaian indikator 6T, yaitu : tepat sasaran, tepat jumlah, tepat harga, tepat waktu, tepat kualitas, tepat adminidtrasi.

\subsection{Program Keluarga Harapan (PKH)}

Program Keluarga Harapan (PKH) adalah program perlindungan sosial yang memberikan bantuan tunai kepada Rumah Tangga Sangat Miskin (RTSM) dan bagi anggota keluarga RTS diwajibkan melaksanakan persyaratan dan ketentuan yang telah ditetapkan. 
Program ini dalam jangka pendek bertujuan mengurangi beban RTSM dan dalam jangka panjang diharapkan dapat memutus mata rantai kemiskinan antar generasi, sehingga generasi berikutnya dapat keluar dari perangkap kemiskinan.

\subsection{Bantuan Siswa Miskin (BSM)}

Program Bantuan Siswa Miskin (BSM) adalah bantuan yang diberikan kepada siswa dari keluarga kurang mampu untuk dapat melakukan kegiatan belajar di sekolah. Bantuan ini memberikan peluang bagi siswa untuk mengikuti pendidikan di level yang lebih tinggi, sebagai tujuan agar siswa dari kalangan tidak mampu dapat terus melanjutkan pendidikan di sekolah. Selain itu juga bertujuan untuk mengurangi jumlah siswa putus sekolah akibat permasalahan biaya pendidikan.

\section{Proses Administrasi Program - Program Bantuan Pemerintah di Kecamatan Madat Kabupaten Aceh Timur.}

\subsection{Bantuan Raskin di Kecamatan Madat Kabupaten Aceh Timur}

Program Beras Untuk Keluarga Miskin (Raskin) merupakan subsidi pangan yang diperuntukkan bagi rumah tangga berpendapatan rendah sebagai upaya dari pemerintah untuk meningkatkan ketahanan pangan dan memberikan perlindungan sosial pada rumah tangga sasaran di Kecamatan Madat Kabupaten Aceh Timur. Dalam hal ini efektivitas penyaluran bantuan raskin di Kecamatan Madat Kabupaten Aceh Timur dapat diukur berdasarkan penjelasan dari para penerima bantuan atau responden. Metode pengukuran efektivitas penyaluran bantuan dilakukan dengan cara melihat apakah penyaluran bantuan tersebut sudah tepat jumlah, tepat harga, tepat waktu, tepat syarat dan bentuk yang diterima.

Berdasarkan jawaban yang diberikan oleh responden terkait dengan indikator efektifitas pemberian bantuan raskin di Kecamatan Madat Kabupaten Aceh Timur, yaitu sebagai berikut: 1. Jumlah bantuan yang diterima oleh masyarakat dinilai $100 \%$ tidak tepat dikarenakan masyarakat hanya menerima $10,5 \mathrm{~kg}$ per rumah tangga dari yang seharusnya diterima yaitu $15 \mathrm{~kg}$ per rumah tangga. Hal ini sudah menjadi kesepakatan bersama karena di Kecamatan Madat Kabupaten Aceh Timur semua masyarakat kecuali PNS berhak menerima bantuan raskin. Pada dasarnya masyarakat yang tidak menerima raskin selain PNS merasa tidak adil dan mempermasalahkan bagaimana kriteria lengkap penerima raskin yang sesuai SOP seperti yang diinginkan pemerintah. Saya juga miskin, saya juga punya banyak anak, kenapa dia mendapatkan raskin, kenapa saya tidak?. Dari sinilah adanya kesepakatan setelah musyawarah bersama bahwa raskin dibagikan ke semua masyarakat kecuali PNS, agar tidak ada lagi konflik antar sesama masyarakat dan pihak yang membagikan raskin.

2. Harga yang dibayarkan oleh masyarakat dinilai $100 \%$ tidak tepat dikarenakan harga tebusan beras raskin yang seharusnya Rp. $1.600 / \mathrm{kg}$ menjadi Rp. $2.000 / \mathrm{kg}$. Biaya distribusi raskin, biaya administrasi di titik bagi dan biaya jaga raskin selama di gudang sudah mencakup semuanya dengan membayar Rp. $2.000 / \mathrm{kg}$, masyarakat juga tidak perlu lagi membawa kantong/goni pada saat mengambil raskin karena sudah disediakan di titik bagi raskin.

3. Waktu penerimaan bantuan raskin dinilai $100 \%$ tidak tepat dikarenakan waktu penerimaan bantuan diberikan setiap 2 bulan sekali dari yang seharusnya diberikan per bulan. Hal ini juga sudah menjadi kesepakatan bersama setelah sebelumnya diberikan per bulan banyak masyarakat yang malas mengambil raskin karena jumlahnya yang sedikit, setelah musyawarah bersama antara geusyik dengan masyarakat maka ditetapkanlah pembagian raskin setiap 2 bulan sekali.

4. Syarat penerimaan bantuan raskin dinilai $100 \%$ sudah tepat dan sesuai dengan SOP program bantuan raskin yang sudah ditentukan, yaitu raskin diberikan untuk Rumah 
Tangga Miskin (RTM) dan terdata sebagai Rumah Tangga Sasaran Penerima Manfaat (RTS-PM) program raskin.

5. Bentuk bantuan yang diterima oleh masyarakat dinilai $100 \%$ sudah tepat dan sesuai dengan SOP program bantuan raskin yang sudah ditentukan. karena semua masyarakat menerima bantuan dalam bentuk beras.

Berdasarkan penjelasan diatas maka kriteria efektifitas pemberian bantuan raskin kepada masyarakat di Kecamatan Madat dapat dijelaskan pada tabel berikut :

Tabel 2. Kriteria Efektivitas Pemberian Bantuan Raskin, Tahun 2016.

\begin{tabular}{lcc}
\hline \multicolumn{1}{c}{ Indikator } & Skor Rata - Rata & Keterangan \\
Jumlah yang diterima & 0 & Tidak Efektif \\
Harga yang dibayarkan & 0 & Tidak Efektif \\
Waktu Peneriman & 0 & Tidak Efektif \\
Syarat Penerimaan & 1 & Efektif \\
Bentuk yang diterima & 1 & Efektif \\
\hline
\end{tabular}

Sumber : Data Primer (Diolah), 2016

Pada tabel 8 dapat dilihat bahwa skor rata - rata untuk indikator jumlah yang diterima, harga yang dibayarkan dan waktu penerimaan adalah 0 (nol) yang berarti bahwa pemberian bantuan raskin kepada masyarakat di Kecamatan Madat tidak efektif. Sedangkan syarat penerimaan dan bentuk bantuan yang diterima sudah efektif dengan skor rata - rata yaitu 1 (satu).

\subsection{Bantuan Program PKH (Program Keluarga Harapan) di Kecamatan Madat Kabupaten Aceh Timur}

Program Keluarga Harapan (PKH) adalah program perlindungan sosial yang memberikan bantuan tunai kepada Rumah Tangga Sangat Miskin (RTSM) dan bagi anggota keluarga RTS diwajibkan melaksanakan persyaratan dan ketentuan yang telah ditetapkan. Secara khusus tujuan PKH adalah untuk mengurangi angka dan memutus rantai kemeskinan, menigkatkatkan kualitas sumber daya manusia, serta mengubah perilaku yang kurang mendukung peningkatan kesejahteraan dari kelompok paling miskin.

Dalam hal ini efektivitas penyaluran bantuan PKH (Program Keluarga Harapan) di Kecamatan Madat Kabupaten Aceh Timur dapat diukur berdasarkan penjelasan dari para penerima bantuan atau responden. Metode pengukuran efektivitas penyaluran bantuan dilakukan dengan cara melihat apakah penyaluran bantuan tersebut sudah tepat tepat jumlah, tepat waktu, tepat syarat dan bentuk yang diterima. Keadaan penyaluran bantuan PKH (Program Keluarga Harapan) di Kecamatan Madat Kabupaten Aceh Timur

Berdasarkan jawaban yang diberikan oleh responden terkait dengan indikator efektifitas pelaksanaan bantuan PKH di Kecamatan Madat Kabupaten Aceh Timur, yaitu sebagai berikut:

1. Jumlah bantuan yang diterima oleh masyarakat dinilai $100 \%$ sudah tepat dan sesuai dengan SOP program bantuan PKH yang sudah ditentukan. Jumlah bantuan uang tunai yang diterima oleh masyarakat sudah sesuai berdasarkan anggota keluarga seperti yang sudah ditentukan dalam SOP program bantuan PKH.

2. Waktu penerimaan bantuan dinilai $100 \%$ sudah tepat dan sesuai dengan SOP program bantun PKH yang sudah ditentukan, yaitu bantuan dibagikan per triwulan. Masyarakat menerima bantuan 3 bulan sekali seperti yang sudah ditentukan dalam SOP program bantuan PKH.

3. Syarat peneriman bantuan dinilai $100 \%$ sudah tepat dan sesuai dengan SOP program bantuan PKH yang sudah ditentukan, yaitu masyarakat penerima bantuan adalah masyarakat miskin sesuai kriteria yang sudah ditentukan dalam SOP program bantuan PKH. 
4. Bentuk bantuan yang diterima dinilai $100 \%$ sudah tepat dan sesuai dengan SOP program bantuan PKH yang sudah ditentukan, yaitu bentuk bantuan berupa uang tunai/cash.

Berdasarkan penjelasan diatas maka kriteria efektifitas pemberian bantuan PKH kepada masyarakat di Kecamatan Madat dapat dijelaskan pada tabel berikut :

Tabel 3. Kriteria Efektifitas Pemberian Bantuan PKH, Tahun 2016.

\begin{tabular}{c|c|c}
\hline Indikator & Skor Rata - Rata & Keterangan \\
\hline Jumlah yang diterima & 1 & Efektif \\
\hline Waktu Penerimaan & 1 & Efektif \\
\hline Syarat Penerimaan & 1 & Efektif \\
\hline Bentuk yang diterima & 1 & Efektif
\end{tabular}

Sumber: Data Primer (Diolah), 2016

Tabel diatas menjelaskan bahwa pemberian bantuan $\mathrm{PKH}$ kepada masyarakat Kecamatan Madat sudah efektif baik dalam hal jumlah bantuan yang diterima, waktu penerimaan bantuan, syarat penerimaan bantuan dan bentuk bantuan yang diterima.

\subsection{Bantuan BSM (Bantuan Siswa Miskin) di Kecamatan Madat Kabupaten Aceh Timur Tahun 2016.}

Program Bantuan Siswa Miskin (BSM) adalah bantuan yang diberikan kepada siswa dari keluarga kurang mampu untuk dapat melakukan kegiatan belajar di sekolah. Bantuan ini memberikan peluang bagi siswa untuk mengikuti pendidikan di level yang lebih tinggi, sebagai tujuan agar siswa dari kalangan tidak mampu dapat terus melanjutkan pendidikan di sekolah. Selain itu juga bertujuan untuk mengurangi jumlah siswa putus sekolah akibat permasalahan biaya pendidikan. Dengan adanya bantuan BSM tersebut diharapkan dapat mensejahterakan kehidupan masyarakat di Kecamatan Madat Kabupaten Aceh Timur.

Dalam hal ini efektivitas penyaluran bantuan BSM (Bantuan Siswa Miskin) di Kecamatan Madat Kabupaten Aceh Timur dapat diukur berdasarkan penjelasan dari para penerima bantuan atau responden. Metode pengukuran efektivitas penyaluran bantuan dilakukan dengan cara melihat apakah penyaluran bantuan tersebut sudah tepat tepat jumlah, tepat waktu, tepat syarat dan bentuk yang diterima.

Berdasarkan jawaban yang diberikan oleh responden terkait dengan efektifitas pelaksanaan bantuan BSM di Kecamatan Madat Kabupaten Aceh Timur, yaitu sebagai berikut 1. Jumlah bantuan yang diterima dinilai $100 \%$ sudah tepat dan sesuai dengan SOP program bantuan BSM yang sudah ditentukan. Jumlah bantuan uang tunai yang diterima masyarak sudah tepat dan sesuai berdasarkan kategori SOP program bantuan BSM.

2. Waktu penerimaan bantuan dinilai $100 \%$ sudah tepat dan sesuai dengan SOP program bantuan BSM yang sudah ditentukan, yaitu masyarakat menerima bantuan per tahun dengan jumlah berdasarkan kategori yang sudah ditetapkan dalam SOP program bantuan BSM.

3. Syarat penerimaan bantuan dinilai $100 \%$ sudah tepat dan sesuai dengan SOP program bantuan BSM yang sudah ditentukan, yaitu bantuan BSM diberikan kepada siswa miskin berdasarkan kriteria yang sudah ditetapkan dalam SOP program bantuan BSM.

4. Bentuk bantuan yang diterima dinilai $100 \%$ sudah tepat dan sesuai dengan SOP program bantuan BSM yang sudah ditentukan, yaitu semua penerima bantuan menerima bantuan uang tunai langsung sesuai SOP program bantuan BSM yang sudah ditetapkan.

Berdasarkan penjelasan diatas maka kriteria efektifitas pemberian bantuan BSM kepada masyarakat di Kecamatan Madat dapat dijelaskan pada Tabel 4. 
Tabel 4. Kriteria Efektifitas Pemberian Bantuan BSM, Tahun 2016.

\begin{tabular}{l|c|c}
\hline \multicolumn{1}{c|}{ Indikator } & Skor Rata - Rata & Keterangan \\
\hline Jumlah yang diterima & 1 & Efektif \\
\hline Waktu Penerimaan & 1 & Efektif \\
\hline Syarat Penerimaan & 1 & Efektif \\
\hline Bentuk yang diterima & 1 & Efektif \\
\hline
\end{tabular}

Sumber : Data Primer (Diolah), 2016

Pada Tabel 4 diatas dapat dilihat bahwa berdasarkan nilai skor yang didapat, maka jumlah bantuan yang diterima, waktu penerimaan, syarat penerimaan, bentuk penerimaan adalah 1 (satu). Hal ini dapat disimpulkan bahwa pemberian bantuan BSM sudah efektif dilaksanakan.

\section{Pengelolaan Program - Program Bantuan Pemerintah di Kecamatan Madat Kabupaten Aceh Timur \\ 3.1 Pengelolaan Bantuan Raskin di Kecamatan Madat Kabupaten Aceh Timur}

Program Raskin (Beras Untuk Keluarga Miskin) bertujuan untuk mengurangi beban pengeluaran Rumah Tangga Sasaran (RTS) melalui Pemenuhan sebagian kebutuhan pangan pokok dalam bentuk beras dan mencegah penurunan konsumsi energi dan protein. Sistem pengelolaan bantuan raskin pada masyarakat umumnya sangat beragam, yaitu ada yang menyimpan sebagai kebutuhan pokok rumah tangga, menjual langsung setelah menerima bantuan dengan alasan lebih membutuhkan uang dari pada beras. Adapun kriteria pengelolaan bantuan raskin di kecamatan Madat Kabupaten Aceh Timur adalah sebagai berikut:

Tabel 5. Kriteria Pengelolaan Bantuan Raskin di Kecamatan Madat Kabupaten Aceh Timur, Tahun 2016

\begin{tabular}{c|c|c}
\hline Kategori Skor & Jumlah Sampel (Orang) & Persentase \% \\
\hline 0 & 0 & 0 \\
\hline 1 & 34 & 100 \\
\hline Jumlah & 34 & $100 \%$ \\
\hline
\end{tabular}

Sumber : Data Primer (Diolah), 2016

Pada tabel diatas dapat dilihat bahwa ada dua kriteria pengelolaan bantuan raskin di Kecamatan Madat yaitu pengelolaan bantuan raskin tidak sesuai dengan tujuan yang ditentukan (kategori skor 0) dan pengelolaan bantuan raskin sesuai dengan tujuan yang ditentukan (kategori skor 1). Dari sampel penelitian dapat dilihat bahwa pengelolaan bantuan raskin di Kecamatan Madat $100 \%$ sudah baik dan sesuai dengan tujuan yang ditentukan yaitu masyarakat menyimpan bantuan raskin untuk dikonsumsi.

\subsection{Pengelolaan Bantuan PKH (Program Keluarga Harapan) di Kecamatan Madat kabupaten Aceh Timur}

Program Keluarga Harapan (PKH) bertujuan untuk mengurangi angka dan memutus rantai kemiskinan, meningkatkan kualitas sumber daya manusia, serta mengubah perilaku yang kurang mendukung peningkatan kesejahteraan dari kelompok paling miskin. Penggunaan bantuan PKH tidak diatur dan ditentukan, tetapi diprioritaskan untuk mengakses layanan pendikan dan kesehatan. Penggunaan bantuan tidak diperbolehkan untuk konsumsi yang merugikan hak anak seperti rokok, minuman keras, judi dan lainnya. Adapun kriteria pengelolaan bantu PKH di Kecamatan Madat Kabupaten Aceh Timur adalah sebagai berikut : 
Tabel 6. Kriteria Pengelolaan Bantuan PKH di Kecamatan Madat Kabupaten Aceh Timur, Tahun 2016

\begin{tabular}{c|c|c}
\hline Kategori Skor & Jumlah Sampel (Orang) & Persentase (\%) \\
\hline 0 & 15 & 44,1 \\
\hline 1 & 19 & 55,9 \\
\hline Jumlah & 34 & 100
\end{tabular}

Sumber : Data Primer (Diolah) 2016

Pada tabel diatas dapat dilihat bahwa sebanyak 15 orang sampel atau 44,1\% dari keseluruhan sampel pengelolaan bantuan PKH di Kecamatan Madat dikategorikan dalam skor 0 atau pengelolaan bantuan PKH tidak sesuai dengan tujuan yang ditentukan yaitu menggunakan bantuan untuk kebutuhan sendiri dan jajan anak. Sedangkan 19 oarang sampel atau 55,9\% dari keseluruhan sampel pengelolaan bantuan PKH di Kecamatan Madat sudah sesuai dengan tujuan yang ditentukan atau dapat dikategorikan dalam skor 1 Hal ini dapat disimpulkan bahwa pengelolaan bantuan PKH di Kecamatan Madat Kabupaten Aceh Timur dinilai kurang baik dikarenakan masih banyak masyarakat yang menggunakan bantuan tersebut untuk tujuan lain.

\subsection{Pengelolaan Bantuan BSM (Bantuan Siswa Miskin) di Kecamatan Madat Kabupaten Aceh Timur}

Bantuan Siswa Miskin (BSM) bertujuan memberikan peluang bagi siswa untuk mengikuti pendidikan di level yang lebih tinggi agar siswa dari kalangan tidak mampu dapat terus melanjutkan pendidikan di sekolah. Selain itu juga bertujuan untuk mengurangi jumlah siswa yang putus sekolah akibat permasalahan biaya pendidikan. Dengan adanya bantuan BSM tersebut diharapkan dapat mensejahterakan kehidupan masyarakat di Kecamatan Madat Kabupaten Aceh Timur. Dana BSM dapat dimanfaatkan untuk pembelian perlengkapan siswa (buku pelajaran, alat tulis, sepatu dan tas), biaya transportasi siswa ke sekolah/madrasah dan uang saku siswa ke sekolah. Adapun kriteria pengelolaan bantuan BSM di Kecamatan Madat Kabupaten Aceh Timur adalah sebagai berikut :

Tabel 7. Kriteria Pengelolaan Bantuan BSM di Kecamatan Madat Kabupaten Aceh Timur, Tahun 2016

\begin{tabular}{c|c|c}
\hline Kategori Skor & Jumlah Sampel (Orang) & Persentase \% \\
\hline 0 & 9 & 26,5 \\
\hline 1 & 25 & 73,5 \\
\hline Jumlah & 34 & 100 \\
\hline
\end{tabular}

Sumber : Data Primer (Diolah) 2016

Pada tabel diatas dapat dilihat bahwa sebanyak 9 orang sampel atau 26,5\% dari keseluruhan sampel pengelolaan bantuan BSM di Kecamatan Madat dikategorikan dalam skor 0 atau pengelolaan bantuan BSM tidak sesuai dengan tujuan yang ditentukan yaitu menggunakan bantuan untuk jajan. Sedangkan 25 oarang sampel atau 73,5\% dari keseluruhan sampel pengelolaan bantuan BSM di Kecamatan Madat sudah sesuai dengan tujuan yang ditentukan atau dapat dikategorikan dalam skor 1. Hal ini dapat disimpulkan bahwa pengelolaan bantuan BSM di Kecamatan Madat Kabupaten Aceh Timur dinilai sudah baik dan sesuai dengan tujuan yang ditentukan.

\section{Manfaat Program - Program Bantuan Pemerintah di Kecamatan Madat Kabupaten Aceh Timur}

Manfaat program bantuan yaitu tercapainya tujuan program-program bantuan yang diharapkan dapat mensejahterakan masyarakat miskin. Adapun indikator dari manfaat program-program bantuan tersebut, yaitu : 
a. Pengeluaran, yaitu mengurangi pengeluaran masyarakat dengan adanya program program bantuan (Skor).

b. Pendapatan, yaitu peningkatkan pendapatan masyarakat dengan adanya program program bantuan (Skor).

c. Tabungan, yaitu peningkatan tabungan masyarakat dengan adanya program -program bantuan (Skor).

Adapun hasil penelitian yang dilakukan di Kecamatan Madat terkait dengan pemanfaatan program bantuan dapat dideskripsikan sebagai berikut :

Tabel 8. Manfaat Program Bantuan Berdasarkan Indikator di Kecamatan Madat Kabupaten Aceh Timur, Tahun 2016

\begin{tabular}{c|c|c|c}
\hline Indikator & Skor & Jumlah Sampel (Orang) & Jumlah (\%) \\
\hline \multirow{2}{*}{ Pendapatan } & 0 & 26 & 76,48 \\
\cline { 2 - 4 } & 1 & 8 & 23,52 \\
\hline \multirow{2}{*}{ Pengeluaran } & 0 & 0 & 0 \\
\cline { 2 - 4 } & 1 & 34 & 100 \\
\hline \multirow{2}{*}{ Tabungan } & 0 & 29 & 85,30 \\
\cline { 2 - 4 } & 1 & 5 & 14,70
\end{tabular}

Sumber : Data Primer (Diolah), 2016

Berdasarkan tabel diatas dapat dilihat bahwa jumlah responden dengan skor 0 pada indikator pendapatan adalah 26 orang, sedangkan jumlah responden dengan skor 1 adalah 8 orang. Pada indikator pengeluaran adanya penurunan pengeluaran dari seluruh responden hal ini dinyatakan dalam skor 1 . Pada indikator tabungan jumlah responden dengan skor 0 adalah 29 orang, sedangkan jumlah responden dengan skor 1 yaitu 5 orang. Apabila pendapatan dan tabungan masyarakat mengalami peningkatan sesudah adanya program bantuan maka skor yang diberikan yaitu 1 (satu). Begitu pula dengan pengeluaran, apabila pengeluaran masyarakat mengalami penurunan sesudah adanya program bantuan maka skor yang diberikan yaitu 1 (satu). Dalam hal ini dapat disimpulkan bahwa program - program bantuan dari pemerintah belum dimanfaatkan dengan baik dan efektif oleh masyarakat di Kecamatan Madat Kabupaten Aceh Timur.

\section{KESIMPULAN DAN SARAN}

Proses administrasi program bantuan pemerintah di Kecamatan Madat Kabupaten Aceh Timur yang meliputi program bantuan PKH (Program Keluarga Harapan) dan BSM (Bantuan Siswa Miskin) sudah efektif sesuai dengan ketentuan yang berlaku, sedangkan program bantuan Raskin (Beras Untuk Keluarga Miskin) belum efektif sesuai dengan ketentuan yang berlaku.

Rumah tangga penerima bantuan Raskin (Beras Untuk Keluarga Miskin) dan BSM (Bantuan Siswa Miskin) sudah mengelola bantuan dengan efektif, sedangkan bantuan PKH (Program Keluarga Harapan) belum dikelola dengan efektif oleh masyarakat di Kecamatan Madat Kabupaten Aceh Timur. Manfaat program bantuan yang mengacu pada indikator pendapatan, pengeluaran dan tabungan masyarakat belum sepenuhnya tercapai.

\section{DAFTAR PUSTAKA}

Arikunto, Suharsini. 2002. Prosedur Penelitian Suatu Pendekatan Praktek. PT Rineka Cipta: Jakarta. 
Hidayat. 2009. Teori Efektivitas dalam Kinerja Karyawan. Gajah Mada University Press: Yogyakarta.

Pusat Bahasa. 2008. Kamus Besar Bahasa Indonesia Pusat Bahasa Edisi Keempat. PT Gramedia pustaka Utama: Jakarta.

Shin, A. Frida. 2010. Efektifitas pelaksanaan Raskin (Studi Kasus: Kelurahan VI Suku Kecamatan Lubuk Sikarah Kota Solok. Fakultas Pertanian Universitas Andalas: Padang.

Sudjana. 2002. Metoda Statistika. Tarsito: Bandung.

Sukirno, Sudano. 2010. Ekonomi Pembangunan: Proses, Masalah, dan Dasar Kebijakan. Prenada Media Group: Jakarta.

Tim Nasional Percepatan Penanggulangan Kemiskinan. 2012. Kumpulan Tanya Jawab Program-Program Penanggulangan Kemiskinan. Sekretariat Wapres RI: Jakarta.

Wanggai, Velix V. 2012. Pembangunan Untuk Semua: Mengolola Pembangunan Regional Ala SBY. Bina Graha: Jakarta.

Winria, Pitapurwati. 2014. Pelaksanaan Penyaluran Raskin Di Kecamatan Sumarorong Kabupaten Mamasa. Skripsi Fakultas Ilmu Sosial Dan Ilmu Politik Universitas Hasanuddin: Makassar 
